\title{
INFÂNCIA, BRINCAR E MEMÓRIA DE INFÂNCIA EM WALTER BENJAMIN: CATEGORIAS DE ESTUDO PASSÍVEIS DE ASSOCIAÇÃO À FORMAÇÃO E À PRÁTICA DOCENTE LIGADAS À INFÂNCIA NO CONTEXTO CONTEMPORÂNEO
}

Claudia Ximenez, Alves ${ }^{1}$

\begin{abstract}
Resumo: Propõe-se neste ensaio apresentar reflexões do pensador Walter Benjamin, buscando explicitar e refletir, especialmente a partir dos ensaios reunidos na Antologia Reflexões sobre a Criança, o Brinquedo e a Educação (2009) e Infância Berliniense por volta de 1900 (1987), sobre a memória, a infância e o brincar como categorias de estudo passíveis de associação à formação e à prática docente ligadas à infância no contexto contemporâneo. Compreende-se que os conceitos benjaminianos mostram-se fecundos para o campo da Educação, especialmente para aqueles que investigam a infância, tornando possível a construção de novas percepções e concepções sobre suas relações com o brincar.
\end{abstract}

Palavras-chave: Infância. Brincar. Memória de Infância. Walter Benjamin.

\author{
CHILDHOOD, CHILD-PLAY AND CHILDHOOD MEMORIES IN WALTER BENJAMIN: \\ CATEGORIES OF STUDY SUSCEPTIBLE TO BE ASSOCIATED WITH TEACHER TRAINING \\ AND PRACTICE RELATED TO CHILDHOOD IN THE CONTEMPORANEOUS CONTEXT
}

\begin{abstract}
In this essay we propose some reflections of the intellectual Walter Benjamin - especially from the essays reunited in the Anthology "Reflections on the Child, the Toy and Education" (2009) and "Berlin Childhood Around 1900" (1987) - intending to explicit and reflect on memory, childhood and child-play as categories of study that can be associated to teacher training and practice related to childhood in the contemporaneous context. We understand that Benjamin's concepts show themselves essential to the field of Education, especially to those who research childhood, rendering possible the construction of new perceptions and conceptions on their relations to child-play.
\end{abstract}

Keywords: Childhood. Child-Play. Childhood Memories. Walter Benjamin.

1 Doutora em Educação Escolar pela Universidade Estadual Paulista, Julio de Mesquita Filho, Unesp. Profa. Adjunto do Departamento de Educação, da Universidade Estadual de Londrina- UEL. E-mail: claudia_ximenez@yahoo.com.br

\begin{tabular}{|l|l|l|l|l|l|}
\hline APRENDER - Cad. de Filosofia e Psic. da Educação & Vitória da Conquista & Ano XII & n. & p. 76-94 & jan./jun.2018 \\
\hline
\end{tabular}


Em Walter Benjamin encontramos elementos que nos permitiram explicitar e refletir sobre as relações entre infância, memória e brincar, no sentido de pensarmos a Educação com e a partir dele. Particularmente os conceitos extraídos de sua teoria, tais como memória, infância, brincar e brinquedos, caros a este texto, se mostraram fundamentais para este propósito.

Especialmente os ensaios História cultural do brinquedo (1987), reunidos na Antologia Reflexões sobre a Criança, o Brinquedo e a Educação (2009) e Infância Berliniense por volta de 1900 (1987), constituídos por ideias originais, críticas e irreverentes do pensamento benjaminiano, serão destacados aqui em maior expressividade, uma vez que atribuem grandeza aos signos da infância e do brincar na infância, particularmente.

Nessa perspectiva, e partindo dessas considerações, iniciamos nossas considerações mencionando Kramer, em seu texto Infância, memória e saber - considerações à luz da obra de W alter Benjamin (1999), quando afirma que a partir de sua perspectiva filosófica, histórica, psicológica, política, antropológica, artística e ética e de seu estilo de escrever, o qual caracteriza como inquietante e instigante, como cronista e narrador da história, categorias que a autora anuncia como sendo indissociáveis, Benjamin nos apresenta seu conceito de infância, "categoria central no conceito benjaminiano de história” (KRAMER, 1999, p. 246).

Em Benjamin, os temas memória, infância e brincar se entrecruzam e são presentificados de forma crítica. Para isso, Benjamin atribui importância fundamental à linguagem, a qual considera, tal como para Vygotsky, elemento mediador do homem na sua história enquanto sujeito.

Para Benjamin, a linguagem é produção humana acontecida na história. Mais do que isso, como assinala Kramer, o homem se faz fazendo o mundo, e se faz como homem se fazendo na linguagem, na relação com o outro. Para isso, a autora afirma ser "no outro que a linguagem se enraíza" (1999, p. 247). Para tanto, o homem, que tem uma infância, se constitui com ela como homem (como sujeito da linguagem) na linguagem. E esclarece: "se o homem é um ser histórico é só porque existe uma infância do homem, é porque ele deve se apropriar da linguagem” (1999, p. 249).

Tal assertiva de Benjamin se desenvolve em estreita relação com a perspectiva dialéticomaterialista de Lev Vygotsky no campo da Psicologia, uma vez que em consonância com seus estudos enfatiza a dimensão histórica da linguagem e atribui uma dimensão materialista à sua concepção de infância e de brincar na infância, especialmente quando trata da relação que estabelece entre linguagem e pensamento.

A este respeito, Pires (2014) afirma que

Benjamin dizia que a criança entra nas palavras como quem entra em cavernas, criando caminhos estranhos em um universo a ser explorado. Algo parecido com o percurso dos poetas, dos artistas ou dos cineastas quando penetram na linguagem, criando seus caminhos, suas errâncias, suas obras, suas montagens, estabelecendo uma relação com o tempo que não é, necessariamente, aquela do tempo linear, 
cronológico, homogêneo e vazio. [...] A infância se constitui num experimentum linguae. De acordo com Giorgio Agamben, ela é entendida como a possibilidade de recuperação da pura expressão; é o momento em que as palavras ainda não estão presas a modelos lógicos abstratos, ou a uma subjetividade essencialmente fabricada, modelada, recebida, consumida (PIRES, 2014, p. 824).

Além disso, aproxima-se à Vygotsky quando distingue em sua teoria a infância desnaturalizada e com identidade própria, da visão de infância romancizada, infantilizada, reducionista e simplista convencionada pelos paradigmas de ciência que racionalizavam-na, individualizavam-na, fragmentavam-na e destituíam-lhe seu caráter subjetivo, complexo e dinâmico.

De acordo com Benjamin, o tempo da infância é o tempo do brincar e o tempo de "agoras", em que passado, presente e futuro relacionam-se numa unidade. Trata-se de um tempo que se abre para diferentes possibilidades. É nesse tempo que Benjamin viaja e reflete sobre os modos de ver de uma criança, sua sensibilidade, valores, estética e historicidade, isso porque designou a memória do brincar como um substrato que além de possibilitar a redenção do sujeito com ele próprio, pode estabelecer liames entre distintas realidades espaciais e temporais, individuais e sociais.

A este respeito, Benjamin observa que a partir das representações veiculadas pela rememoração de uma situação lúdica, o adulto pode aludir à sua infância, e assim, perceber a origem de suas experiências e concepções sobre brincar. Tal como um fio que tece a experiência, o autor afirma que as rememorações da infância de um adulto são acionadas porque a criança pulsa neste adulto que escreve e está presente em si, em sentido pleno. Todavia, ele explica que este adulto não compreende a percepção infantil porque muitas vezes a visualiza através de sua própria perspectiva espaço-temporal linear, fragmentada e mecânica, que racionaliza as possibilidades de sedimentação da experiência na memória.

Assim procedendo deixa entrever a ideia que lhe é tão cara de que a cultura adulta se impregna de uma cultura infantil, na medida em que o passado de uma infância esquecida pode ser reinventado no presente da vida adulta. Para Benjamin, assim como na infância ficam adormecidos vários adultos possíveis, nos adultos vivem adormecidos várias infâncias possíveis.

Para Benjamin, sob a lógica das lembranças, é possível reparar e ver o que se manifesta no outro e fora de si.

Podemos conferir na citação do texto "Velhos brinquedos: sobre a exposição de brinquedos no Märkische Museum" uma cena onde um pai se vê encantado enquanto adulto, diante de um brinquedo dado ao filho:

Conhecemos aquela cena da família reunida sob a árvore de Natal, o pai inteiramente absorto com o trenzinho de brinquedo que ele acabou de dar ao filho, enquanto este chora ao seu lado. Não se trata de uma regressão maciça à vida infantil quando o adulto se vê tomado por um tal ímpeto de brincar. Não há dúvida que brincar significa sempre libertação. [...] mas o adulto, que se vê acossado por uma realidade 
ameaçadora, sem perspectivas de solução, liberta-se dos horrores do real mediante a sua reprodução miniaturizada. (BENJAMIN, 2009, p.85).

Ainda em relação a possíveis viagens no tempo e nas memórias de infância de um adulto, Benjamin declara que nos diferentes modos de ser da criança e nas diferentes expressões das culturas da infância, o adulto organiza uma forma de perceber o seu mundo. Rememorá-los, então, sugere compreender que não se está diante de um único modo de se construir a história, pois ao se ressignificar, como tal, as perspectivas da criança e de sua experiência no mundo, recorda-se com ela a infância que habita em si.

Isso mostra o quanto os escritos benjaminianos atribuem grandeza ao passado, sobretudo quando propõem a ruptura do "era uma vez" acreditando que ao resgatar o passado, o presente no homem marca um encontro secreto com as gerações precedentes. Nesse modo de ver, quando o homem acessa o passado, através de sua memória, não o faz sem reescrevê-lo e vinculá-lo a experiências do seu presente.

Em vista desta forma de atribuir sentido ao passado e à memória como parte da experiência humana, dando ênfase à sua condição histórica e mutante, Benjamin (1987) explicita a infância e o brincar em sua teoria, associando-as às relações identificadas entre memória e história na modernidade.

Para o autor, a memória é concebida como reveladora do homem, na medida em que, para ele, como já dito anteriormente, quando o adulto acessa o passado o realiza no presente quando o rememora, participando, assim, ativamente de seu tempo e de sua história.

E por falar, ainda, sobre o modo como desvela a infância, sua construção teórica, extremamente ousada em relação à Educação, aparece especialmente quando em Infância Berliniense por volta de 1900 (1987) reconstitui a própria infância por meio de reminiscências e lembranças de sua memória apresentando-nos, neste exercício de escrita narrativa, suas concepções a respeito da cultura lúdica infantil. Isso nos é representado em experiências vividas em espaços, formas de brincar e tipos de brinquedos constituídos por (e constituintes de) sua história de sua vida, logo, seu paradigma de interpretação.

Quando Benjamin propõe-se a definir o que é ser criança em suas obras, escritas em textos curtos, sua intenção é condensar nelas uma experiência coletiva na representação de uma criança cuja história estava delimitada a um tempo de transformações sociais, culturais e políticas profundas: isto porque viveu algumas das crises fundamentais do sistema capitalista na Europa: a Primeira Guerra Mundial, o nazismo, o fascismo, o stalinismo, bem como o início da Segunda Guerra Mundial.

Assumindo uma posição política, o pensador relata lembranças e impressões advindas de experiências infantis de um menino rico e sensível cujo mundo perceptivo se confronta e se enraíza com o mundo histórico, enquanto aprendizado e criação de seu mundo. 
A partir da palavra de um adulto exilado e crítico atento, desvela detalhes e segredos de um cotidiano que reflete e condensa experiências e imagens de revoltas e desejos coletivos vividos na Berlim do Segundo Império.

Em um cenário que se industrializa rapidamente e que se transforma em metrópole do dia para a noite, despontando como potência econômica imperialista, o garoto Benjamin vagueia, observa e medita pelas ruas e galerias da cidade, casas de amigos, cafés, zoológico, fontes, lojas e caminhos das escolas e se recorda dos passeios com sua mãe, do jeito de caminhar um passo atrás, atento a emoções, lugares, pessoas e paisagens. É deste modo, portanto, que o filósofo percebe o mundo sob sua perspectiva, assim como relembra e reinventa sua infância, com extrema riqueza de detalhes, apresentando-nos elementos que habitar(a)m este momento de sua vida, atribuindo atenção, sobretudo, a objetos, costumes cotidianos e pequenas coisas que, de tão familiares, poderiam não ser notadas por outrem.

O que nos parece emergir de modo transparente em seus textos é uma linguagem muito particular e próxima à de uma criança que narra em meio ao calor dos acontecimentos, com descrições minuciosas. Nesse sentido, Benjamin recupera, em certo sentido, a maneira de ver da criança, sua sensibilidade e valores. Sob esse ângulo, os ensaios que retratam esta infância podem ser lidos como se fossem relatos escritos e impressões subjetivas de uma criança para outra criança, no bojo de uma cultura lúdica infantil. Particularmente a obra Rua de Mão única (1987), escrita em 1933, foi dedicada ao seu filho Stefan e com ela, Benjamin manteve vivo, através da criança e de sua visão sobre ela, a representação de fatos, sensações, personagens e objetos de uma infância ainda muito presente no adulto de quarenta anos que narra.

Jeanne-Marie Gagnebin (2004, p. 80) assinala que o trabalho da memória e vínculo do passado/presente em Benjamin permite a seu leitor visualizar as imagens de um passado infantil que volta para iluminar o presente por uma coincidência súbita que não depende da memória voluntária do sujeito, visto que não é tida como algo fruto de um acaso. Afirma a autora, que Benjamin dirige sua atenção para fora e, assim, objetiva tal memória numa não-tentativa de rever os êxtases da infância, tal como podemos observar nesta afirmação do autor a respeito:

Quem pretende se aproximar do próprio passado soterrado deve agir como um homem que escava. Antes de tudo, não deve temer voltar sempre ao mesmo fato, espalhá-lo como se espalha a terra, revolvê-lo como se revolve o solo. Pois "fatos", nada são além de camadas que apenas à exploração mais cuidadosa entregam aquilo que recompensa a escavação. Ou seja, as imagens que, desprendidas de todas as conexões mais primitivas, ficam como preciosidades nos sóbrios aposentos de nosso entendimento tardio, igual a torsos na galeria do colecionador. E certamente é útil avançar em escavações segundo planos. Mas é igualmente indispensável a enxadada cautelosa e tateante na terra escura. E se ilude, privando-se do melhor, que só faz o inventário dos achados e não sabe assinalar no terreno de hoje o lugar no qual é conservado o velho (BENJAMIN, 1987, p. 239). 
No pensamento benjaminiano se assenta a busca de compreensão sobre sua cidade de origem, Berlim, assim como o retrato de seu convívio social. Sem linearidade, dialogando com outros personagens em diferentes tempos, espaços e papéis, ora como criança-criança, ora como criançaadulto, caminha entre presente e passado, passado e presente, revisitando sua história de infância a partir de seu próprio olhar:

[...] e assim esse parque, que, como nenhum outro, parece aberto às crianças, era desfigurado para mim pelo difícil, pelo irrealizável. [...] Quantas vezes procurei em vão a mata onde se erguia um quiosque com torrezinhas vermelhas, brancas e azuis, no estilo de um jogo de encaixe de peças! [...] Mais tarde descobri novos rincões; sobre outros aprendi coisas novas. [...] Por isso, quando trinta anos mais tarde um conhecedor da terra, camponês de Berlim, assistiu-me no retorno à cidade, após afastamento comum de longa duração, seus passos araram esse jardim no qual semeou a semente do silêncio. [...] Conduziam para baixo, senão para a origem de todos os seres, certamente para a desse jardim. No asfalto que pisava, seus passos despertavam um eco (BENJAMIN, 1987, p. 74).

Evidencia-se, neste excerto, que quando Benjamin faz referências às memórias da infância as interpreta como experiência atrelada ao passado, arraigadas ao conhecimento e às experiências da realidade de um contexto histórico acentuado por grandes modificações territoriais.

Nesse sentido, ao passear por suas memórias de infância, Benjamin faz uma reflexão de seu passado a partir do olhar crítico de adulto, trazendo para seu texto não somente sua memória individual, mas um quadro histórico social que envolve uma memória coletiva mais abrangente. Ao rememorar, se preocupa em narrar sua infância como lugar de não razão e de não linguagem.

Os conceitos por ele utilizados, tais como memória, narração, rememoração, reminiscência, infância, cultura, brincar, brinquedos e modernidade (especialmente nas obras reveladoras destas questões, aqui antes mencionadas), partem de um estilo onde o passado do narrador perpassa experiências pessoais que provocam naquele que o lê uma reação empática que desperta e evoca reminiscências de uma infância imaginada, recriada, perdida e reencontrada pelo e no sujeito que a acompanha.

Benjamin reúne lembranças, apresentadas sob o ponto de vista do eu-narrador, da voz subjetiva e confessional do autor, e recortes de experiências infantis vividas com adultos, brinquedos, escola e livros e(m) espaços significativos em sua formação. Neste caso, ao transitar por entre seus ensaios, se é possível revisitar lugares e percorrer tais espaços de sua história de vida, atualizando experiências por meio de lembranças-fragmentos de seu brincar, brinquedos e brincadeiras.

Nestes momentos, recorda e descreve brincadeiras e explorações de uma criança contemporânea, ele mesmo, que adora colecionar e, portanto, conservar brinquedos e miniaturas de realidade, numa forma de atribuir, assim, novas configurações a objetos e artefatos, então plenos de ritualidade e signos. Neles encontramos uma tessitura de um adulto que retoma acontecimentos que 
permeiam sua interioridade a partir de experiências objetivas de sua existência e subjetivas que pesquisou, organizou e sobre o qual se debruçou, tal como o faz no excerto abaixo.

Durante muito tempo, o que delas me fazia recordar era a caixa espaçosa na parede de meu quarto, com os primórdios de uma coleção de borboletas [...] Relembravam as ardorosas caçadas [...] se uma vanessa ou esfinge que comodamente poderia ter alcançado zombasse de mim com vacilações, oscilações e flutuações [...] Entre nós começava a se impor o antigo estatuto de caça: quanto mais se achegava com todas as fibras ao inseto, quanto mais assumia intimamente a essência da borboleta, tanto mais ela adotava em toda ação o matiz da decisão humana, e, por fim, era como se sua captura fosse o único preço pelo qual minha condição de homem pudesse ser reavivada (BENJAMIN, 1987, p.80-81).

Segundo Adorno (1987), tais experiências podem ser vistas como sendo de um adulto que olha a si mesmo, como se fosse possível observar e sentir em um ponto quase externo de sua interioridade mesma. Ele mesmo, enquanto criança, a procura de si mesmo pelo exercício da memória, é narrado em primeira pessoa, em um processo que associa história, memória e experiência do passado à luz do presente, no sentido objetivo e subjetivo que se possa admitir. Assim, condensa e compartilha aquilo que recorda, na singularidade de sua história de infância, da criança que foi. Nesse sentido, pensamos que seja possível então compreender como Benjamin articula história e memória, relacionando presente, passado e futuro, instigado pela rememoração, desvelando não "uma vida como de fato foi, e sim uma vida lembrada por quem a viveu" (BENJAMIN, 1987, p.37).

Nesse processo, o universo infantil é apresentado tal como em um jogo de quebra-cabeças, haja vista o fato de que o autor intercambia lembranças representadas como tendo sido reais e/ou imaginárias.

A este respeito, Marchi (2011) assinala que

Em Infância em Berlim, WB relata as lembranças e impressões das ruas e monumentos históricos de sua cidade natal, os feriados, os passeios ao zoológico e ao parque de diversões, as férias na praia, as visitas familiares, a casa dos pais e seus armários-esconderijo, a escrivaninha em seu quarto, o furto às guloseimas na despensa, os brinquedos, os dias de escola e os dias enfermo na cama, a novidade da técnica (telefone, cinema, etc.), os personagens nas ruas que sinalizavam a descoberta das desigualdades sociais - mendigos e prostitutas, entre outros temas que habitaram sua infância de menino rico. Todos esses temas são percorridos detalhadamente pelo trabalho de sua memória (MARCHI, 2011, p. 225).

E assim o passado é desvelado através de imagens, sons, aromas e metáforas, próximas e distantes. Do aroma de maçã assando no forno na manhã de inverno à criança que passeou e entregouse a diferentes territórios e objetos de sua casa, os acontecimentos revelam-nos, pelos labirintos da memória, a curiosidade, o encantamento e a estranheza implicados em sua narrativa (assim como em sua filosofia, literatura e crítica).

Portanto, em nós, fica-nos a impressão de que sua particular experiência do passado nos aproxima, enquanto leitores, de nossa própria experiência e cultura infantil, visto que a criança presente 
no adulto (em Benjamin) nos permite reconhecer e desvelar o passado, à luz de um presente que vai sendo decifrado e reinventado à medida que o agora dialoga com o ontem, simultaneamente e descontinuamente.

Tal como afirma Galzerani (2002), Benjamin como adulto rememora sua infância, retomando a poesia desta fase, sem se distanciar das coisas as quais se referia. Nesse caso, o adulto exilado que escreve teoria sem fazer teoria, é o filósofo que dialoga com as suas experiências vividas, sem situá-las em uma lógica temporal etapizada e progressiva. Assim, Benjamin aproxima-se do objeto que focaliza, sem perder a relação com eles.

Alguns leitores de suas obras, tal como Marchi (2011), Kramer (2008) e Galzerani (2002), alegam que em muitos fragmentos identifica-se uma autobiografia, ainda que o próprio autor não nos autorize a categorizá-la como tal, aliada à subjetividade do filósofo:

Em suas recordações do passado, deixa transparecer a perda do eu através do tempo que só o sujeito, abrindo mão de sua subjetividade, da temporalidade e do espaço de sua vida, mobiliza. Dilui-se não o sujeito que escreve, mas a identidade através do tempo, do objeto, do espaço. Na objetividade que aparece, pode ser fundada a experiência coletiva. A subjetividade é permeada, por algo mais expressivo que ela; algo que permite que, num indivíduo, toda uma época possa se expressar: a linguagem. (KRAMER, 2008, p. 20-1).

Ainda segundo Galzerani (2002, p.59), o autor

produz, pois, uma transformação radical da visão clássica de autobiografia, já que focaliza não apenas lembranças pessoais, mas a vibração de uma memória pessoal e coletiva. Não fala dele apenas. Fala de um nós, na relação com os outros. Rememora a criança que foi, articulada a outros personagens. Criança na relação com crianças, com adultos, situados em diferentes categorias sociais. (GALZERANI, 2002, p.59).

Nessa direção, Marchi (2011) assinala com seu leitor a seguinte indagação:

[...] não nos enganemos quanto a essa possível e estreita aparência biográfica ou "memorialista": o que WB faz ao escrever sobre fatos, emoções, personagens e objetos que povoaram sua infância é atualizar, para além da sua particular experiência do passado, uma "infância universal", ainda que marcada pelo viés de classe: o menino que estudava, passava férias à beira-mar, recebia presentes de Natal em um lar grande e aquecido (MARCHI, 2011, p. 225).

E prossegue:

Quando se lê Infância em Berlim pela primeira vez, fica-se certamente com a dúvida: o texto é do adulto escrevendo sobre a criança que foi ou é a própria criança que escreve? Tal dúvida vem do extremo detalhamento e proximidade do narrador com os fatos, sensações e objetos descritos. É uma memória tão minuciosa e arbitrária que há a impressão de que a descrição foi feita no calor dos fatos, no momento mesmo dos acontecimentos (MARCHI, 2011, p. 225).

A este respeito, Vaz comenta:

O tema da infância em Benjamin, [...] alcança um significado metodológico, estrutural no seu pensamento. Seja pela rememoração - fundamental para aquele que quer ser 
capaz de narrar histórias -, porque, para Benjamin, a experiência é uma categoria histórica essencial [...] (VAZ, 2010, p. 46).

Partindo de referências que se mantinham vivas em sua memória, Benjamin assume uma posição de cronista que faz a história de pequenos acontecimentos do capitalismo pós-industrial e escreve como quem busca preservar os valores da infância. Para isso, alia história e linguagem através da narrativa e a coloca como recurso para se compreender e acessar o passado, entendido como obra inacabada. Assim, privilegia o ato de rememorar e afirma ser através dele possível despertar experiências significativas e esquecidas.

Por esta perspectiva de análise, torna-se possível perceber como as categorias e conceitos infância, criança, brinquedo, brincar e brincadeira são apresentados por Benjamin, entrelaçados à sociedade contemporânea pós-século XX.

Particularmente em relação ao conceito de criança, Benjamin crê que ela, indivíduo social inserido numa história, pertencente a uma classe social, produtor e produto de sua cultura, apreende o mundo através da capacidade de percepção de afinidades e semelhanças, atribuindo-lhe outras relações de pertencimento e temporalidade. Acredita que a criança brinca com seus brinquedos, reconhecendo neles o caráter de objeto passível de confronto e, assim, identifica-se com ele para compreendê-lo, através de sua imaginação, criatividade e sensibilidade.

Para o autor, brincar significa expressar-se diante da vida, significa conhecer e produzir o conhecimento de si e do mundo; renovar os sentidos dados para sua realidade; questionar e criticar suas imposições de sujeição e submissão a valores instituídos pelos adultos; traz em si a dimensão simbólica que produz o sujeito, na medida em que testemunha a realidade psíquica da criança.

Ao compreender que a herança simbólica se faz valer no brincar, Benjamin (1994, p. 252) chama atenção para o fato de que as brincadeiras de perseguição (gato e rato), defesa (goleiro, tenista) e luta (disputa por uma bola) revelam a oscilação na qual a criança vai se tornando autônoma de si mesma.

Com respeito a isso, o próprio Benjamin afirma que existe um duplo sentido na palavra spielen, que diferencia o brincar do representar, pois para ele, "a essência da representação, como da brincadeira, não é faz̧er como se, mas fazẹ sempre de novo, é a transformação em hábito de uma experiência devastadora" (1987, p. 253).

Nesta forma de entendimento, as experiências sociais de uma criança, atualizadas em brincadeiras e jogos, permitem-na representar e reelaborar a realidade livremente através da incorporação de papéis sociais os mais diversos. Com isso, a criança reconhece e reproduz semelhanças com sua realidade, diferenciando-as de uma imitação propriamente dita. Em outras palavras, Benjamin via na criança a possibilidade de recuperação da expressão humana, visto que as crianças não somente recordam (ou imitam) o mundo dos adultos, mas dele se apropriam criativamente atribuindo-lhe novos 
sentidos. Enfim, as observações benjaminianas sobre o brincar infantil não deixam dúvida, a nosso ver, quanto ao seu caráter criativo, elaborativo e, também, rememorativo e repetitivo.

Sobre isso, Almeida (2006, p. 546) afirma que

O conceito de mimese envolve, em última análise, a diluição de si para fins de aproximação com o outro. Por este motivo, a brincadeira torna-se um ritual mimético no momento em que a criança consegue diluir-se no espaço, no lugar e no tempo para dar significado ao objeto que manipula ou aos inúmeros papéis que representa com relativa tranquilidade nas diversas vezes que brinca (ALMEIDA, 2006, p.546).

Nas palavras de Pires (2014), “[...] Nos escritos de Benjamin, a produção mimética estará relacionada, como em Aristóteles, ao jogo e ao aprendizado, ao conhecimento e ao prazer de conhecer". Neste caso, conforme Benjamin salienta, as crianças estão ligadas ao mundo muito mais do que pensamos, captam sua essência, se sentem atraídas pelas atividades adultas, sem deixar de criar um mundo simbólico que alimenta seu imaginário.

Para brincar é necessário um tempo para encontrar-se consigo mesmo, com a sua história, com a sua subjetividade, com suas experiências de vida, com seu acervo particular de imagens recolhidas e experiências vividas e imaginadas. Este tempo que não é apenas cronológico e linear, mas psicológico e fragmentado, portanto subjetivo. Tempo próprio da infância, que se transforma em curso singular e particular na vida de cada um, tempo reflexo do nosso tempo sócio histórico e cultural.

Nesse sentido, partilhar como o menino Benjamin de suas memórias de infância em seus textos significa não sair dela somente com as suas lembranças de lugares, objetos e experiências as mais diversas, mas com o corpo todo tomado.

No fragmento Ampliações (1987), encontramos a criança lendo, chegando atrasada, petiscando, andando de carrossel, desordenando, assim como em Criança Escondida (1987), vemos o coração batendo, a respiração suspensa, em que Benjamin ilumina, de modo comovente, a criança "encerrada no mundo da matéria", e parece abrir com as mãos, a cortina atrás da qual ela se torna "algo ondulante e branco como um fantasma...atrás da porta ela própria é porta...e a casa é o arsenal das máscaras" (pp. 40-41).

Em Criança Desordeira (2009), apresenta o modo infantil de ver e se apropriar do mundo, suas afinidades e sentidos atribuídos aos objetos do mundo que a circundam. Sua forma de se identificar e compreender as coisas, transformando-as e nelas transformando-se quando brincam, fica evidente em:

Toda pedra que ela encontra, cada flor colhida e toda borboleta capturada já é para ela o começo de uma coleção. Na criança, esta paixão revela o seu verdadeiro rosto, o severo olhar de índio, que continua a arder nos antiquários, pesquisadores, bibliômanos, porem com um aspecto turvo e maníaco. Mal entra ela na vida e já é caçador (BENJAMIN, p. 107).

Tomando estas considerações a respeito de Benjamin, as palavras de Schlesener (2011) muito bem as sintetizam: 
Uma das ideias mais instigantes que perpassam os escritos de Benjamim é a de infância, vinculada às reflexões sobre a experiência moderna, à natureza e ao uso da linguagem [...], à reconstrução da história a partir de detalhes e ruínas, à temporalidade como repetição ou como criação que, no conjunto do seu pensamento, são questões que se entrelaçam (SCHLESENER, 2011, p. 129).

Dentre outras questões, que julgamos pertinentes, destacamos a que se refere ao modo como Benjamin compreende a experiência infantil enquanto experiência histórica produzida e que se produz no mundo urbano, a qual, segundo ele, carece de experiências corporais que advenham dos sentidos ligados ao olhar e às mãos, experiências estas que se materializam fortemente nos brinquedos.

Para exemplificar esta consideração, em As Cores, percebe-se nitidamente sua capacidade de articular, por meio de brincadeiras com as palavras, até porque este brincar, para Benjamin, é visto como prática de linguagem, a dimensão da consciência e da inconsciência (termo que remete à Psicanálise proposta por Freud e de quem Benjamin foi interlocutor) que atravessa sua narrativa:

Em nosso jardim havia um pavilhão abandonado e carcomido. Gostava dele por causa de suas janelas coloridas. Quando, em seu interior, passava a mão de um vidro a outro, ia me transformando. Tingia-me de acordo com a paisagem na janela, que se apresentava ora chamejante, ora empoeirada, ora esmaecida, ora suntuosa. [...] Coisa semelhante se dava com as bolhas de sabão. Viajava dentro delas por todo o recinto e misturava-me ao jogo de cores de suas cúpulas até que se rompessem. Perdia-me nas cores, fosse nos céus, numa joia, num livro. [...] Naqueles dias, podia-se comprar bombons de chocolate em graciosos pacotinhos, nos quais cada tablete em forma de cruz era embrulhado em papel de estanho colorido. Essas pequenas obras, amarradas por um áspero barbante dourado, reluziam com seu verde e amarelo, seu azul e laranja, seu vermelho e prateado; em parte alguma das peças da mesma cor se tocavam. Vencendo esse cintilante obstáculo, aquelas cores irromperam um dia sobre mim, e ainda sinto a doçura com que meu olhar então se saciou. Era a doçura do chocolate com que as cores iam se desfazer mais em meu coração que em minha língua. Pois, antes que eu fosse derrotado pela sedução das guloseimas, esse senso superior, com um golpe, sobrepujou em mim o inferior, me arrebatando (BENJAMIN, 2009, p.101-102).

Nos dois excertos abaixo, mais uma vez seu olhar de adulto se conjuga ao tato experimentado e rememorado de e em sua infância:

Pela fresta do guarda-comida entreaberto sua mão avança como um amante pela noite. Uma vez familiarizada com a escuridão, tateia em busca de açúcar ou amêndoas, uvas passas ou compotas. E assim como o amante abraça sua amada antes de beijá-la, da mesma forma o tato tem um encontro preliminar com as guloseimas antes que a boca as saboreie. Como o mel, punhados de passas e mesmo o arroz, como todos entregam-se lisonjeiramente à mão! Quão apaixonante esse encontro de dois que finalmente se subtraíram à colher. Agradecida e selvagem, como uma moça que se rouba da casa dos pais, assim a geléia de morangos se oferece aqui à degustação, sem o pãozinho e como que sob o livre céu de Deus, e mesmo a manteiga retribui com ternura a ousadia de um pretendente que tomou de assalto o seu quarto de menina. A mão, o jovem Don Juan, penetrou logo em todas as celas e aposentos, deixando atrás de si camadas que escorrem e quantidades que fluem: virgindade que se renova sem queixas (BENJAMIN, 2009, p. 105-106). 
Nada superava o prazer de mergulhar a mão em seu interior tão profundamente quanto possível. E não apenas pelo calor de lã. Era tradição enrolada naquele interior que eu sentia na minha mão e que, desse modo, me atraia para aquela profundeza...Tudo o que era guardado a chave, permanecia novo por mais tempo...Mas meu propósito não era conservar o novo e sim renovar o velho (BENJAMIN, 2009, p. 105-106).

Fica evidente, nestes fragmentos, a combinação de experiências sensoriais, a partir do qual Benjamin experimenta cheiros, texturas, densidades e espessuras de objetos e lugares.

Em Elogio da boneca (1985), Benjamin mostra a paixão que tinha por brinquedos e brincadeiras, que implicavam para ele uma libertação, tanto que alia essa passionalidade a uma genialidade especulativa e poética, que o leva a conceber o brinquedo como "categoria" atrelada ao universo infantil, com peculiaridades que admitem diversas configurações. Sobre isso, Benjamin afirma que o brinquedo carrega em si toda a cultura em que se insere sua produção: desde a época a qual se vincula, até um modo de ver o mundo e de se relacionar com as crianças, passando também pelo modo de educar e apresentar o legado de uma geração, em outras palavras, um projeto de sociedade. Afinal, Benjamin, dentre as inúmeras questões que suas críticas suscitam, se refere a uma possível e crescente massificação própria da evolução industrial, a qual inscreve o brinquedo em uma dimensão de homogeneização (MEIRA, 2003), despertada após o final da guerra, dos brinquedos infantis, dos objetos e da cultura. Com isso, para Benjamin, a faculdade mimética ou de sua transformação vem sendo extinta pelos modos de produção capitalista da modernidade juntamente com "o apagamento da singularidade, a plastificação dos brinquedos, [...] que avança revelando seus contornos inclusive no campo da infância” (MEIRA, 2003, p. 75) e incide diretamente sobre o brincar infantil e o uso de alguns brinquedos como a boneca e o pião, os jogos de tabuleiros e os contos de fadas, por exemplo.

Segundo Benjamin, o comerciante de brinquedos do século XVIII e XIX era o vendedor doméstico de ferragens e de marcenaria, que produzia os brinquedos nas oficinas manufatureiras de entalhadores em madeira, de fundidores de estanho, de fabricantes de velas e de confeiteiros de doces. Era o artesão pouco especializado que considerava o brinquedo como um produto com traços peculiares, e que assim, combinava uma técnica primitiva com um material rudimentar, que aproximava pais a filhos. [...] "assim como se podia encontrar animais de madeira com o marceneiro, assim também soldadinhos de chumbo com o caldeireiro, figuras de doce com o confeiteiro, bonecas de cera com o fabricante de velas" (BENJAMIN, 1984, p. 68).

Em História cultural do brinquedo (1987) e em Velhos Brinquedos: sobre a exposição de brinquedos no Markische Museum (2009), Benjamin reconhece o declínio da simplicidade dos brinquedos, assim como se preocupa com a artificialização e fragmentação de seu uso, que associa ao processo de industrialização do lúdico e da infância, que propicia à criança o distanciamento com os adultos, com o imaginário e com o processo de criação próprio do brincar. No segundo texto, ora mencionado, mais 
especificamente, o ensaísta apresenta uma sucessão de críticas a este universo designado como cenário de objetos do mundo lúdico infantil representado por adultos ${ }^{2}$.

Nesse sentido, sua crítica, pensada na contramão das leituras contemporâneas elaboradas até então, nos ajuda a compreender que, sob a lógica da sociedade do consumo, os brinquedos, assim como muitas brincadeiras infantis, impregnam as marcas das transformações sociais e culturais, a começar pela representação como objeto e bem de consumo que incorpora e reproduz diante das prerrogativas do mercado. Para ele, o brinquedo é um objeto cultural fortemente suscetível às nuances ditadas pelo materialismo cultural. Benjamin associa o fato de que a partir do século XIX a venda de brinquedos passa a se tornar um ramo da indústria, em consonância com o reconhecimento da infância. Isso, percebendo que a criança passa, então, na mesma medida, a ser vista como potencial consumidor.

Chama a atenção nitidamente em suas notas a forma como se opõe intensamente ao mercado moderno que fabrica brinquedos sob aspectos que desconsideram a infância na sua natureza particular, atribuindo-lhe traços que caracterizam o que o adulto concebe nele, a partir de sua perspectiva, e não aquilo que a criança deseja em relação ao brinquedo. Pensando assim, o autor polemiza severamente a forma como a criança vem interagindo com o brinquedo, uma vez doutrinada e condicionada pelos adultos que o produzem.

Como exemplo de tal apontamento, percebido como reflexo de tal transformação, Benjamin critica o processo de plastificação e de homogeneização dos brinquedos, chegando a prenunciar, assim, o processo de virtualização, tecnologização e didatização crescente destes, na associação que estabelece entre imagem e lúdico. De acordo com o filósofo, de pequenos objetos os brinquedos tornam-se maiores e perdem sua identidade, subvertendo-se ao controle dos adultos, ao universo decorativo e à indiferença da criança. Assim, os brinquedos refletem a transformação e as peculiaridades culturais e históricas pela qual passa a infância contemporânea nas suas íntimas vinculações com o brincar. É assim que Benjamin se refere ao processo de mercantilização do brinquedo e da criança, que, a seu modo crítico de observar, pode ser percebido tanto nos tipos de materiais (da madeira ao plástico, por exemplo) quanto na forma de produção e formato dos brinquedos, que impõem novas configurações em termos de relação entre estes e as crianças.

Para Benjamin (2009, p. 99), as lojas de brinquedos passam a caricaturizar o capital econômico moderno condicionando-o em brinquedos cujas formas e processos de produção contrastam com o caráter e formato artesanal e popular (como já mencionado anteriormente) que conferiam aos brinquedos um traço de simplicidade relacionado intimamente a seu criador, que, por sua vez, combinava, segundo ele, uma técnica primitiva com um material rudimentar. Na concepção

\footnotetext{
${ }^{2}$ Entre os brinquedos apresentados e sobre ele refletidos, são anunciados desde cavalos de madeira até soldadinhos de chumbo, bonecas de resina e/ou de cera e trenzinhos. No texto "Velhos brinquedos: sobre a exposição de brinquedos no Märkische Museum", escrito em 1928, Benjamin se depara com uma exposição, neste mesmo ano, no "Museu distrital brandenburguês", que apresentava velhos brinquedos de antigas famílias locais de Berlim. A exibição apresentava obras de artesãos manufatureiros da Alemanha do século XVIII e XIX. Acredita-se que essa exposição tenha despertado em Benjamin sua curiosidade e potencializado seus estudos sobre os brinquedos infantis.
} 
benjaminiana, o brinquedo, materializado no espírito capitalista de seu tempo, passou a distanciar a criança da produção do artefato. Todavia, o autor não destitui da criança sua capacidade de confrontarse com a existência circundante, atribuindo-lhe sentidos próprios. Para tanto, afirma:

O espírito do qual descendem os produtos, o processo total de sua produção, e não apenas o seu resultado, está sempre presente para a criança no brinquedo, e é natural que ela compreenda muito melhor um objeto produzido por técnicas primitivas do que um outro que se origina de um método industrial complicado (BENJAMIN, 2009, p. 127).

Particularmente nos ensaios Rua de mão única (1987) e Infância em Berlim por volta de 1900 (1987), Benjamin faz críticas contundentes ao processo de didatização e pedagogização o qual considera presente desde o Iluminismo, limitante ao reconhecimento dos potenciais da criança para transformar os sentidos e funções para os quais os brinquedos, livros e demais objetos educativos foram criados. A este respeito, comenta: “[...] Enquanto cândidos pedagogos permanecem nostálgicos de sonhos rousseaunianos, [...] pintores como Paul Klee, captaram o elemento despótico e desumano nas crianças. As crianças são insolentes e alheias ao mundo.” (BENJAMIN, 1987, p.86).

Nessa mesma perspectiva, Benjamin critica tanto o autoritarismo de idade que submete e subjuga as crianças, entendendo ser esta uma representação de pedagogia anti-educativa, quanto reconhece o adultocentrismo presente nas relações sociais e escolares, como reflexo de um processo de naturalização e infantilização da infância (e da cultura). A este respeito, declara: “ jamais são os adultos que executam a correção mais eficaz dos brinquedos - sejam eles pedagogos, fabricantes ou literatos -, mas as crianças mesmas, no próprio ato de brincar.” (BENJAMIN, 1987, p. 87). Nas palavras de Pires (2014, p. 822), para Benjamin, “a educação não é propriedade privada da pedagogia”.

Diante desta perspectiva, o ensaísta vê na criança o potencial transformador da educação. Nestes termos, reconhece as crianças, assim como os rituais de infância, como potencialmente responsáveis pela constituição do sujeito moderno. Para o filósofo, a brincadeira infantil, enquanto ritual mimético, permite à criança transformar e atribuir novos significados tanto aos espaços com os quais interagem, quanto aos objetos com os quais se relacionam e papeis que representam. E nesse sentido, através deles, podem permitir ao adulto a compreensão dos processos históricos de construção de saberes.

Para ele, a criança sofre a cultura, ao mesmo tempo que também a transgride e a inventa. $\mathrm{Na}$ citação a seguir, Armários, observamos um tempo infantil tecido artesanalmente, através de uma criança desordeira que brincava fazendo com que objetos falassem e ecoassem no adulto-criança que conservava, no qual as lembranças não se apagavam:

O primeiro armário que se abriu por minha vontade foi a cômoda. Bastava-me puxar o puxador, e a porta, impelida pela mola, se soltava do fecho. Lá dentro ficava guardada minha roupa. Mas entre todas as minhas camisas, calças, coletes, que deviam estar ali e dos quais não tive mais notícias, havia algo que não se perdeu e que fazia 
minha ida a esse armário parecer sempre uma aventura atraente. Era preciso abrir caminho até os cantos mais recônditos; então deparava minhas meias que ali jaziam amontoadas, enroladas e dobradas da maneira tradicional, de sorte que cada par tinha $\mathrm{o}$ aspecto de uma bolsa. Nada superava o prazer de mergulhar a mão em seu interior tão profundamente quanto possível. E não apenas pelo calor da lã. Era a "tradição" enrolada naquele interior que eu sentia em minha mão e que, desse modo, me atraía para aquela profundeza (BENJAMIN, 1987, p. 122).

É nessa perspectiva benjaminiana que se é possível compreender como brinquedos e brincadeiras infantis documentam o modo de o adulto se colocar em relação ao mundo da criança, uma vez que significativas interações da criança com o adulto e seu universo social passam pelo brincar e uso de brinquedos.

Diante de tudo isso, é possível pensar que a íntima relação que Benjamin estabelece entre brinquedo, brincar, cultura, infância, experiência, história e memória, é pontuada pelo autor quando atribui importância à história do brinquedo e à memória do brincar, momento em que promove interações entre a criança (contemporânea) e seu mundo através da memória de sua infância.

Segundo Meira (2003), em Benjamin, os brinquedos e a infância contemporânea, para Benjamin, a memória do brincar, hoje apagada pelo excesso paradoxal de oferta fortuita de objetos às crianças, pode ser resgatada através de novas vias narrativas que operem a aproximação da criança a seus pares e à cultura. (p. 85). Desta sorte, Benjamin entende que experiências do passado podem ser evocadas oralmente por professores e alunos e que assim, sentidos diversos podem ser abertos à experiência infantil através de infinitas possibilidades que a linguagem pode oferecer. Isso porque, para ele, memória, conhecimento, experiência e linguagem são conceitos que se confundem e se fundem, paradoxalmente, e ao mesmo tempo, especialmente na infância.

Giorgio Agamben (2005), filósofo italiano contemporâneo, importante referência, hoje, na compreensão de Benjamin, no ensaio O país dos brinquedos: reflexões sobre a história e sobre o jogo (2005) problematiza o valor do jogo e da brincadeira na vida cotidiana dos homens. Assim como o faz Benjamin, em sua análise convergem os conceitos de infância e história, percebendo-os como não lineares.

As palavras de Gomes (2007, p. 254), acerca deste estudo, afirmam que, para Agamben, "não cabe a ideia da infância como etapa de uma ordem cronológica, porque a infância é uma potência que permite a renúncia do previsível e ilumina aquilo que não se revela de imediato”. E prossegue, “a infância coloca o indivíduo no lugar de produtor da cultura e, com outros interlocutores, ele acrescenta significação ao mundo".

Segundo Benjamin, no mundo dos brinquedos, mais particularmente no mundo da criança que brinca, se aproximam e misturam-se pedras, plásticos, metais, vidro, madeira, papel, ossos, tecidos ou argila. Estes materiais são mimetizados e transformados em brinquedos numa relação de entrega, emancipação, contemplação e supremacia em relação ao objeto, resistência à banalização, criação e repetição: 
Ninguém é mais casto em relação aos materiais do que crianças: um simples pedacinho de madeira, uma pinha ou uma pedrinha reúnem na solidez, no monolitismo de sua matéria, uma exuberância das mais diferentes figuras (BENJAMIN, 2009, p.92).

Para Benjamin, na brincadeira da criança é o conteúdo imaginário e simbólico que determina sua atividade lúdica e não os objetos-brinquedos que utilizam (na sua dimensão material): a criança quer puxar alguma coisa e torna-se cavalo, quer brincar com areia e torna-se padeiro, quer se esconder e torna-se bandido ou guarda. Com efeito, contesta a crença de que a criança subordina-se ao brinquedo.

Nesses termos, Pires (2014) afirma que

Benjamin contesta a crença de que um suposto preestabelecido conteúdo imaginário do brinquedo vem a determinar a brincadeira da criança. Ao definir esse pensamento como "grande equívoco" (BENJAMIN, 1996, p. 250), ele afirma que a relação da criança com o brinquedo dá-se na direção contrária, é na brincadeira que a criança busca incluir o seu brinquedo ou objeto de brincar": "a criança quer puxar alguma coisa e torna-se cavalo, quer brincar com areia e torna-se padeiro, quer esconder-se e torna-se ladrão ou guarda" (BENJAMIN, 2009, p. 93).

De todo modo, o brinquedo é visto, por Benjamin, como um instrumento híbrido e dialógico, que permite à criança manipulá-lo conforme seus interesses e desejos: [...] "para a criança que brinca sua boneca ora é grande, ora é pequena, [...] pois se trata de um ser subordinado" (BENJAMIN, 2009, p.98).

E nesse sentido,

[...] a experiência social da criança atualizada na brincadeira e no jogo encontra-se permeada por condutas miméticas, que lhe permitem ir além da sua capacidade de produzir semelhanças para lançar-se à transmutação entre os diversos e possíveis papéis sociais, pelos quais ela transita livremente [...]. (BENJAMIN, 2009, p. 99).

Junior, Alcântara e Cintra (2012) em “O problema da modernidade em Walter Benjamin: uma abordagem sobre a infância e a educação", também se referem às significações que as crianças atribuem ao brinquedo, quando afirmam que "[...] para o filósofo, a criança é quem atribui significação ao brinquedo, utilizando-se da ludicidade e do imaginário que lhe são próprios” (2012, p. 140). Segundo os referidos autores, para Benjamin, "o brinquedo e o próprio brincar dispõem de ampla relevância social”, além de carregarem consigo forte "significado como objeto histórico". (2012, p. 140).

Segundo Almeida (2006), a criança quando brinca dilui-se no brinquedo (fundindo-se a ele) em uma relação quase que simbiótica, o que destitui a ideia de que esse objeto lúdico determina sua brincadeira e seu imaginário a ela relacionada. Neste caso, o brinquedo assume o caráter simbólico de "instrumento de brincar" e não apenas material que promove interação e criatividade (BENJAMIN, 1987, p. 70).

Brincar com um brinquedo, em Benjamin, assume, na criança, a experiência que lhe permite o refúgio, a perda, o (re)encontro, o domínio de si e o acesso ao outro. Brincando a criança liberta-se e 
reedita papéis sociais criando para si um mundo próprio: habitual, intenso e renovado. A criança, para Benjamin, imita, incorpora e traduz o realismo do universo adulto para o cenário lúdico infantil, onde tudo pode ser livremente subvertido.

Atrás do cortinado, a própria criança transforma-se em algo ondulante e branco, converte-se em fantasma. A mesa de jantar, debaixo da qual ela se pôs de cócoras, a faz transformar-se em ídolo de madeira em um templo onde as pernas talhadas são as quatro colunas. E atrás de uma porta, ela própria é porta, incorporou-a como pesada máscara e, feita um sacerdote-mago, enfeitiçará todas as pessoas que entrarem desprevenidas. [...] Quem a descobrir pode fazê-la petrificar-se como ídolo debaixo da mesa, entretê-la para sempre com fantasma na cortina, bani-la pelo resto da vida na pesada porta (BENJAMIN, 2009, p. 107-108).

Nesse contexto, é percebida como sujeito portador de uma natureza cujo imaginário pode ser constituído e reconstituído por personagens sombrios, grotescos e cruéis no ato de brincar.

Pequenos atentados terroristas maravilhosamente executados, com príncipes que se despedaçam, mas que voltam a se recompor; incêndios que irrompem automaticamente em grandes lojas, invasões e assaltos. Bonecas-vítimas que podem ser assassinadas de diversas formas e seus correspondentes assassinos com todos os seus respectivos instrumentos; guilhotina e forca [...]. (BENJAMIN, 2009, p. 87).

Assim, fica-nos evidente que tanto a criança quanto a experiência infantil esboçada por Benjamin aparecem sempre vinculadas ao mundo do brinquedo, percebido enquanto produto material, simbólico, cultural e social. Este brinquedo, em si, é apresentado como extensão de seu próprio corpo, confundindo-se com ele, por vezes, como sujeito.

A criança é aquela que reconstrói e ressignifica de um modo compreensível os brinquedos, no ato de brincar. Brincando, a criança renova o antigo, reconstrói a lógica do adulto e experimenta algo novo. Nesse sentido, “[...] uma vez extraviada, quebrada e consertada, mesmo a boneca mais principesca transforma-se numa eficiente camarada na comuna lúdica das crianças" (BENJAMIN, 2009, p. 87). Neste caso, para Benjamin, o brinquedo é submetido às necessidades da criança, misturase com seus significados e inspira vida aos objetos mudos e sem movimento, esquecidos ou abandonados pelos adultos. Além disso, o brinquedo se constitui como potente instrumento de diálogo da criança com o que a cerca em seu cotidiano e com sua própria história, oferecendo-lhe subsídios ao seu contexto social.

Segundo Benjamin, a criança quer sempre repetir a vitória da aquisição de um saber-fazer, desejando incorporá-lo a seu repertório de ações. O adulto, em sentido contrário, rememora no brincar suas experiências vividas, como se pudesse reencontrar os significados de sua infância, devolvendo-lhes a oportunidade de serem redescobertos nas suas práticas cotidianas.

Para o autor, a criança exige dos adultos explicações claras e inteligíveis, mas não explicações infantis, aceita perfeitamente coisas sérias, mesmo as mais abstratas e pesadas, desde que sejam honestas e espontâneas (BENJAMIN, 1984, p. 236-237). 
Nestes termos, a criança estabelece uma espécie de jogo com as palavras e a realidade, apropriando-se de significados diversos, no sentido de produzir novos e outros sentidos. Atenta à detalhes, especialmente àquilo que o adulto deixou escapar, procura atentar as margens, sendo seu olhar aberto a novas formulações. Com isso, a incompletude lhe pertence e the abre perspectivas para um fazer sempre de novo.

Ainda nesta direção, em Canteiro de Obras (1987), o filósofo fala da irresistível atração das crianças "pelo resíduo que surge na construção, no trabalho de jardinagem ou doméstico, na costura ou na marcenaria". É nesses restos que reconhecem "o rosto que o mundo das coisas volta exatamente para elas", e é com esse material que esculpe seu mundo (pp. 18-19).

Em síntese, das reflexões que foram elaboradas, ao longo deste ensaio, podemos dizer que, pensar a Educação com e a partir de Walter Benjamin significa compreender crianças como sujeitos sociais competentes, complexos, completos e imersos na trama cultural, social e histórica de seu tempo; e perceber, tal como Santos (2015, p.232) já afirmara, que "a criança deve ter o direito, principalmente quando inserida em contextos educacionais, de viver a plenitude de sua infância [...]" e que, para tanto, $[\cdots]$

Isso pressupõe que entre si, brincando e nas diversas formas de relações com seus pares, as crianças criam para si um pequeno mundo cultural próprio. Mundo esse produzido num fecundo diálogo pelo qual elas não apenas garimpam, no amplo mundo sociocultural dos adultos, aspectos a serem reproduzidos, mas oferecem-nos inovadoras formas ativas, genuínas e interpretativas com as quais percebem e recriam as relações sociais e a cultura. Ou seja, as crianças se sentem convidadas por vários objetos e demais aspectos do mundo cultural, sem depender de qualquer autorização ou solicitar para se relacionar com eles. Desse modo, muitas vezes aquilo que os adultos preparam - julgando ser mais adequados a elas - é o que menos lhes desperta interesse. (SANTOS, 2015, p. 233).

Nestes termos, tal como já ressaltado por Marchi (2011, p. 228), o “pioneirismo de Walter Benjamin e a genialidade em seus escritos sobre a infância e a possibilidade por ele aberta de repensarmos seu(s) sentido(s) na modernidade", permitem-nos acreditar que os conceitos benjaminianos mostram-se fecundos para o campo da Educação, especialmente para aqueles que investigam a infância, tornando possível a construção de novas percepções e concepções sobre suas relações com o brincar. Outrossim, os ensaios de Benjamin nos permitem considerar a memória, a infância e o brincar como categorias de estudo passíveis de associação à formação e à prática docente ligadas à infância no contexto contemporâneo. 


\section{REFERÊNCIAS}

ADORNO, Theodor. Educação e Emancipação. Rio de Janeiro: Paz e Terra, 1987.

AGAMBEN, Giorgio. Infância e história: destruição da experiência e origem da história. Tradução Henrique Burigo. Belo Horizonte: Editora UFMG, 2005.

ALMEIDA, D. B. L. Sobre brinquedos e infância: aspectos da experiência e da cultura do brincar. Educação \&o Sociedade, vol.27, n.95, maio/ago.2006.

BENJAMIN, W. Infância em Berlim por volta de 1900. In: Rua de Mão Única. São Paulo: Brasiliense, 1987. p.71-142. (Obras escolhidas, v.2).

Reflexões: a criança, o brinquedo e a educação. São Paulo: Duas Cidades, 2009.

GALZERANI, M. C. B. (2002). Imagens entrecruzadas de infância e de produção de conhecimento histórico em Walter Benjamin. In A. L. G. de Faria, Z. de B. F. Demartini, \& P. D. Prado (Orgs.), Por uma cultura da infância: metodologias de pesquisa com crianças (pp. 49-68). Campinas: Editores Associados.

GAGNEBIN, J-M. História e narração em Walter Benjamim. São Paulo: Perspectiva, 2004.

GOMES, L. O. A infância do homem. Resenha da obra AGAMBEN, G.. Infância e história: destruição da experiência e origem da história. Trad. Henrique Burigo. Belo Horizonte: Editora UFMG, 2005, 188p. In: Pro-Posições, v. 18, n. 3 (54) - set./dez. 2007.

JUNIOR, A.; ALCÂNTARA, A.C.; CINTRA, R. E.A. et al. O problema da modernidade em Walter Benjamin: uma abordagem sobre infância e a educação. Revista Sapiência, Iporá, v. 1, n. 2, p. 130-145, jul./dez. 2012.

KRAMER, S. Infância, memória e saber - considerações à luz da obra de Walter Benjamim. A Criança e o Saber, Rio de Janeiro, v. 1, p. 245-249, 1999.

MARCHI, R.C.M. Walter Benjamin e a infância: apontamentos impressionistas sobre sua(s) narrativa(s) a partir de narrativas diversas. Educação, Porto Alegre, v. 34, n. 2, p. 221-229, maio/ago. 2011.

MEIRA, A. M.; Benjamin, os brinquedos e a infância contemporânea. Revista Psicologia e Sociedade: 15(2); 74-87, jul/dez 2003.

PIRES., E. G. Experiência e linguagem em Walter Benjamin. Educ. Pesqui., São Paulo, v. 40, n. 3, p. 813-828, jul./set. 2014.

SANTOS, Sandro Vinicius Sales dos. Walter Benjamin e a experiência infantil: contribuições para a educação infantil. Pro-Posições [online]. 2015, vol.26, n.2, pp.223-239.

SCHLESENER, A. H. Educação e Infância em alguns escritos de Walter Benjamin. Paidéia. 21 (48): p.129-135, jan/abril 2011.

VAZ, A. F. Educação, experiência, sentidos do corpo e da infância (um estudo experimental em escritos de Walter Benjamin), In: PAGNI, P. A.; GELAMO, R. P. (Org.). Experiência, educação e contemporaneidade. São Paulo: Cultura Acadêmica, 2010. p.35-49. 
Recebido em: 14 de maio de 2018. Aprovado em: 16 de jun ho de 2018. 